\title{
The Correlation of Women's Purchasing Power and New Trend In Japan's Popular Music Industry
}

\author{
Sekar Hayuning Galih ${ }^{1}$, Susy Ong ${ }^{2}$

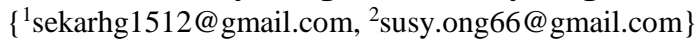 \\ ${ }^{1,2}$ School of Strategic and Global Studies, Universitas Indonesia, Jakarta, Indonesia
}

\begin{abstract}
This study discusses the correlation of the increasing of women's purchasing power and the emergence of new trends in Japan's popular music industry in the last 2 decades. Data from the yearbook of Recording Industry Association of Japan in 2018 shows that there is a change of trend in Japan's popular music industry after the year 2000. The data stated that the group of idols consisting of several men (the so-call 'boy bands'), such as Exile and Arashi, achieve the position as the best artist for several consecutive years. I argue that since Exile and Arashi are boygroups, their fans are mostly women. That these women are able to 'consume' their idol, indicates that they are indeed financially well-off. Why? I assume that their opportunities for higher educations during the 1980s, combined with high employment rate, have enpowered them financially as well as socially. Furthermore, I will show an overview of the trends of the music industry in the Japanese popular music industry from the 1980s to the 1990s. Finally, the discussion part will show the correlation how the changing financial position of Japanese women can affect the dynamics of Japan's popular music trends.
\end{abstract}

Keywords: women, financial ability, popular music, female gaze

\section{INTRODUCTION}

Japan is a country in the East Asia region that can be categorized as a developed country. The entertainment industry is developing well in this country, including one of the popular music industries. The history of the Japanese popular music industry began when the music industry entered the United States to Japan in the 1930s (Stevens, 2009). The technology referred to in this context is sound recording technology (audio recording). Since then, singers from various genres under the umbrella of Japanese popular music began to appear. Responding to the phenomenon of the development of the popular music industry, Japanese society seemed to receive it well. Various musical genres developed in Japan and each genre has its own listeners. Over time, various record companies in Japan formed associations under the name Recording Industry Association of Japan (RIAJ) in 1942. Since recording technology entered from America to Japan, the establishment of the RIAJ in 1942 indicated that Japan's popular music industry was developing quite rapidly because this happens in less than decades. In addition, the RIAJ which has its own site provides information about the Japanese popular music industry in broad outline. The information is summarized in the form 
of an annual book which contains the highest album sales reports, songs that are ranked top, and the best artist rankings every year.

As we also know, the popular music industry which is included in the entertainment industry category shows different trends at each time. This is usually influenced by the conditions of a society that changes dynamically. Based on data from the 2018 RIAJ yearbook, there is an interesting thing to do with the trend of artists in the Japanese popular music industry. In the 1990s until the mid-2000s, the winner of the Best Artist of the Year ranking in the domestic category was dominated by young female singers such as Namie Amuro, Utada Hikaru, Hamasaki Ayumi, and Koda Kumi. However, different conditions have been seen since 2008. In 2008 and 2009, the position of Best Artist of the Year was won by EXILE. EXILE is a Japanese boy band consisting of 15 people at that time (now there are 19 people). Then the position was achieved by ARASHI in 2010, 2011 and 2014 to 2017. ARASHI is a Japanese boy band consisting of 5 people. Based on these data, we can see that since 2008 a new trend has emerged in the Japanese popular music industry, namely the emergence of idol groups. An idol group consisting of men is even able to get top rankings compared to the early years of their debut.

The conditions reflected in the RIAJ yearbook are interesting because of changes in trends in the Japanese popular music industry. Usually, producers will create and sell a product if the market is promising. The emergence of singers packaged in the form of idol groups in Japan began to bloom since the early 2000s. This was also marked by the beginning of ARASHI's debut in 1999. Then for less than a decade, they received special attention in the popular music industry. If calculated from the 1990s in Japan which is a period of lost decades, this trend has emerged around 1 decade since that time. This can raise allegations about consumption of idol groups, especially boy bands, which are produced by entertainment agencies in Japan. A product usually appears and is sold because there are consumers who will buy the product. In general, male artist fans usually come from women. Fans who come from men do exist and this is undeniable, but in this context it can be said that the majority of boyband fans come from women.

Based on the conditions described in the previous paragraph, we can assume that women in Japan have the financial ability to consume commodities produced by the entertainment industry. The commodities referred to in this context are Japanese boy bands in the popular music industry. Historically, the level of women's education in major cities in Japan at the beginning of the 20th century influenced their lifestyle and the nature of their consumerism. Women in this big city usually get education that is equivalent to elementary school. This is enough to equip these women with basic literacy skills. They began to express their interest in popular culture at that time through magazines or radio. This led to the widespread spread of trends such as fashion, film and popular music among women (Sato, 2003).

Based on the explanation above, we can see conditions similar to the beginning of the $21 \mathrm{st}$ century. Changes in the level of women's education are reflected in the increasing number of women who have received education up to junior college or even universities (MEXT, various years). Increasing the level of women's education supports them in getting jobs. The higher the level of education, the type of work obtained will be more feasible, especially for the formal sector. Women who graduate from junior colleges or universities will usually be preferred by companies compared to those who graduated from junior or senior high school. Therefore, the level of education of women affects the type or type of work in the formal sector they will get. 
If a woman gets a job with a position as a permanent employee, then it can be assumed that automatically she will get a fixed income. Fixed income in this context means the income of a permanent employee who is guaranteed and the amount will increase with the length of time he works in a company. This was caused by Japanese companies that adopted the shushin koyosei system. Women who have a fixed income can be assumed as a market for the popular music industry, especially as an audience for boyband as a commodity.

Based on the data and several assumptions that have been described above, the author draws on the formulation of the problem of how to correlate the increase in women's financial ability with the formation of new trends in the Japanese popular music industry? To dissect the problem, the author uses the literature study method by collecting various valid data then analyzing it to get answers from the formulation of the problem.

\section{CONCEPT FRAMEWORK}

The concept framework that will be used in this study consists of two types, namely visual pleasure and consumption of the pop music industry products. Boyband as a product of the popular music industry appeared as a "watched" figure by its fans. This is quite related to visual pleasure or visual satisfaction that was triggered by Laura Mulvey. At a time when this opinion was triggered, the consumption conditions of popular cultural products in the Western world were still in the male structure as subjects or figures who watched, while women as objects or figures were watched. From Mulvey's opinion, we can see that the conditions at that time were dominated by male gaze or male views. Men as spectators have the power to choose women like what they want to witness. From these activities, the audience will get visual satisfaction from the results of consuming a spectacle that shows women with certain characters or appearances that can satisfy their views.

If we relate to the conditions of boyband trends that occur in the Japanese popular music industry, things that happen are almost similar but reversed. This time, the female gaze holds the power role. The female fans became the figures who watched, and the male members of the boyband were watched. The female fans are free to like which members of the boyband they like most, leading to the process of imagination or fantasizing about the members of the boyband; so by watching boyband as their idol, they will get visual satisfaction. In connection with Exile and Arashi, this is still relevant.

To analyze the formulation of the problem in this study, a related concept is needed to support the conceptual framework that has been described previously. The concept used is consumption of idols related to the production-consumption scheme of popular music. This consumption concept refers to the relationship between fans and their idols, namely fans who idolize their favorite artists or celebrities as the ones they worship. According to Galbraith and Karlin (2012), women in Japan not only idolize artists from Japan but also artists from South Korea. Nevertheless, the idol that is favored by female fans has in common: a man with a handsome and charming face. Kim in Stevens (2012) stated that the female gaze of the women not only became male gaze's "competitors", but also increased the position of women in society who had been in the subordinate position. At the same time, the women were able to break the conservative view that women who approach middle-aged and above are humans who experience a decline in sexuality (Galbraith and Karlin, 2012). This is evidenced by their passion, imagination, and fantasy towards their idols, not with real physical relationships. In 
addition, according to Anne and Allison (2006) in Galbraith and Karlin (2012), interactions between fans and their idols can be formed through several popular cultural products such as fan-meetings and watching concerts. Although interactions that occur in such events can be said to be unreal, the process of doing so still gives meaning to fans who are willing to spend their time and money for the event. Through this example, it can be said that anything can be an object to vent the desire or passion of the fans. In this context, capitalist society can be said to rely on people who channel their desires or passions through satisfaction when consuming something.

In connection with the explanation above, the process of consumption of idols is related to the process of consumption of products of the popular music industry. The passion or desire of the fans is not only limited to fantasy but is realized through events such as fan-meetings and concerts, as well as the purchase of albums and official merchandise. This means, besides consuming idols, fans also consume other products produced by the popular music industry an industry that houses these idols. Entertainment agencies that in this context play a role as producers to form these idols in such a way that they become special "products" that can be sold by entertainment agencies. By seeing these women as a market, usually the type of product will be adjusted to target markets or consumers. Therefore, the relationship between consumers and producers is formed "indirectly" through the process of consumption of idols.

\subsection{Correlation of Women's Financing and Education Skills in Japan}

The history of women's education in Japan has passed a long time. In this point will be explained about the history of women's education in Japan and its relation to women's work and financial abilities. It is suspected that this can also be a factor that causes the dynamics of trends in society. A woman who gets education and then gets a job in the formal sector as an employee still indicates that she will definitely get a steady income. Therefore, the level of education achieved by women can determine the opportunity to get a decent job.

Compulsory education for four years was first put into effect in 1886. It then developed to six years in 1907 and became nine years in 1947. Then, the number of women who could get education began to increase slightly even though the numbers were still very small. This change in society and the form of household life is thought to be a factor that has led to the proliferation of education for adults, especially for women (Nuita, 1972). Then in 1959, NHK launched the Women's Classes program on radio and television. This broadcast provides discussion topics to increase the level of culture and living conditions of women. The audience or listener is divided into several small groups according to the same theme or interest, then they can discuss for free (Nuita, 1972). Although in reality the condition of women in Japan is still hit by the problem of gender relations, but in fact there has been a real effort or action to improve their standard of living. This shows that in fact Japanese society after Meiji realized that education for women was important. It's just that, implementation and goals are still not right. Because this study discusses trends in Japan's popular music industry after 2000, the situation in the world of education for women in Japan will be displayed starting from the 1990s to be more relevant.

The education system in Japan is divided into several stages. A child will go through six years of primary education and junior secondary education for three years. Then they can choose whether to continue to technical college for five years or high school education for 
three years. The secondary education in question is divided into two, namely academic schools and vocational schools. For students who choose to continue to senior secondary education for three years, they can then continue their education to the junior college level for two years or university for four years (Yu, 2009). According to Okano and Tsuchiya in Yu (2009), as many as pertama junior high school students in Japan choose to continue their education to academic schools, not vocational schools.

As reported by garbagenews.net, it is seen that students who continue their education to junior college and university level are increasing every year. Over a period of about a decade since 1990, the number of students who continue to higher education is more female than men. This figure was initially only around $37 \%$ in 1990 and then touched 50\% in 2000. After 2000, the number of women who continued to higher education institutions continued to increase but the percentage was still below men. This shows that in the 1990s were times when the number of women who continued to higher education institutions was more than men. We can see more clearly about these conditions through the image below.

Through the explanation above, we can find out that the percentage of women who went on to higher education institutions in the 1990s was higher than men. But does this indicate that more women continue to university level - higher education for four years? Apparently not. Based on data from the Japanese statistical yearbook in Yu (2009), there are data that can display details of these conditions. From the overall percentage of women who continue their education to tertiary institutions, almost $90 \%$ of them continue to junior college level, not university. The number of women who went to junior colleges increased rapidly in the span of 20 years, between 1950-1970. It was then in a stable condition around 80\% in 1970-2000. Different things were seen at the university level. The percentage of women who continued to university level in 1950 was not up to $10 \%$, only around $9 \%$. This figure then increased to around $35 \%$ in 2000. That is, an increase in the percentage of women who continued to university level was not too significant for the size of the 50-year period. Although the increase was not significant as the number of participants who went to junior colleges, basically the number of women who continued to tertiary education after senior high school continued to increase.

The conditions described above occur not without cause. There are several things that cause women to choose to continue their education at the junior college level and not at university. Family norms in Japan emphasize academic education to be inculcated in their sons (Yu, 2009). In addition, having two or three years of education at a junior college is considered more suitable for women and it will be easier for them to get a job than going to university (Shirahase, 2014). This shows that although there are obstacles that come from the norms prevailing in society, women in Japan try to improve their standard of living. With an orientation to get a job, it means they don't just want to continue their education higher than high schoool seniors but also to be able to work and have financial skills independently. Japanese women today are no longer limited to junior high school or senior high school graduates but higher than that. It is normal if they get a job that matches their level of education. Usually, the higher the level of education a person will affect the work they get. The scope of women's education in this context is up to the level of junior colleges and universities with undergraduate degrees. Therefore, the type of women's work in question is work in the formal sector with their position as permanent employees. 
During the bubble economy in Japan, the absorption of labor by various companies was very high. Moreover, they would be employed as permanent employees (Fukuda, 2013). This happened until the early 1990s. But then the condition changed after the Japanese economy experienced a recession after the bubble economy ended (Dasgupta, 2009). Nevertheless, we can see that the condition of women in the world of work is changing. Based on data from Nagase, Nawata, and Mizuochi (2011) in Fukuda (2013), it appears that since the early 1990s there has been a decline in the number of female senior high school graduates who later get jobs as permanent employees. In contrast to women who graduated from levels above senior high school, the female charts that got permanent employment seemed to fluctuate, but both declined. From these data, we can see that the percentage of women who are more permanent employees is those whose education level is above senior high school. That is, this can be a trigger for women to continue their education after graduating from senior high school. This is because they will be more guaranteed to get a permanent employee position compared to only senior high school graduates.

This condition shows that although there is a decrease in employment, both men and women, there is an increase in women's education. By getting a permanent job, they will get a fixed income. The group of women who have this financial ability can be said to be a market for the Japanese popular music industry. In the late 1990s, the Japanese popular music industry offered boy bands as the product they sold. Therefore, a new trend can emerge if it is successfully marketed and consumed by many people.

\subsection{Overview of Trends in Japan's Popular Music Industry: 1970s-1990s}

To see the condition of the trend of Japanese popular music in general, the trend of the 1970s and 1990s will be outlined to be more relevant. In the 1960s to mid 1970s the trend of Japanese popular music was rock music. Then in the 1980s there emerged a techno-pop trend and the term J-pop emerged. Popular music in these years is more cheerful and varied compared to the previous decade (Cope, 2007). The huge surge of consumerism in the 1960s also affected the popular music industry. With a huge surge in consumerism, the economic flow in the music industry is able to reach all walks of life (Attali, 1985) and spread very quickly. The famous band at that time was the Tigers and Group Sounds (Bourdaghs, 2012). Music trends until the mid-1970s were still dominated by the nuances of rock because of the mass production of electric guitars at affordable prices (Hiroyuki, 2000) and the media highlighted rock music in those days (Bourdaghs, 2012). Then, Matsutoya Yumi a.k.a Yuming became one of the singers most highlighted since the late 1970s. He is a singer-songwriter who is then regarded as an artist who is able to bring artistic integrity in the world of Japanese popular music (Bourdaghs, 2012).

Techno-pop music was introduced by the Yellow Magic Orchestra (YMO) in the 1980s. The group formed by Sakamoto Ryuichi uses the sounds of electronic manipulation results in his songs. Besides YMO, the duo group Chage and Aska also occupied important positions in the trend of Japanese popular music at the time. The 1980s also became an important period for the development of the Japanese popular music industry because the term J-pop first appeared in 1988 on Tokyo FM radio broadcasts (Bourdaghs, 2012). After the bubble economy era ended, the types of music offered by the Japanese popular music industry varied. In addition to trends from solo singers such as Utada Hikaru and Hamasaki Ayumi, boy band 
trends such as the emergence of SMAP and Arashi are also being offered this decade. In addition, visual-side bands such as L'arc en ciel and X-Japan also have many fans even though they are not as booming as other types (Stevens, 2008).

Based on the presentation of the trends of the popular music industry in Japan, we can see that popular music trends can change. This condition is very natural, not only in Japan but also in various countries around the world. This can be influenced by various factors, but especially those that relate to the economic conditions of the community at that time. Therefore, the emergence of boy band trends in the 1990s and flourishing after 2000 can certainly be influenced by the economic conditions of Japanese women.

\section{DISCUSSION}

Based on the explanation of the data described above, we can see the common thread or linkages between points to analyze the problem in this study. Bennett in Dore (1967) stated that rapid growth in Japanese economy is exerting an impact on many important sectors. This may be associated with high industrialization and development of a consumer economy within the society. According to Sand in Smith (2018), young urban consumers in the 1980s and 1990s have concluded that their ambivalence is developed from a paradox of sensibilities. They longed for something outside Japan's society consumer managed, but they were captive to its fashions.

Menurut Adorno (1991) dalam Negus (1996), the popular music that was being distributed by the music industries as mass culture required the listener to make very little effort, because usually the listeners reject everything that was not familiar. Frith (1988) menyatakan bahwa the industrialization of music cannot be understood as something that happens to music, since it describes a process in which music itself is made. Twentieth-century popular music means the twentieth-century popular record; not the record of something which exists independently of the music industry, but a form of communication which determines what songs, singers, and performances are and can be (Negus, 1996). What about the characteristics of the Japanese music industry? Basically, record companies, which serve as the cornerstone of the Japanese music industry, tend to resist change under the influence of outside factors. This is evident in the resale price maintenance system, under which the price of a CD is maintained at $¥ 3,000$ (Mitsui, 2014).

The production system includes the artists who transform ideas into popular culture artifacts, and all the people who develop the artifacts from the original form into marketable items. Agents, producers, managers and executives are active here in making decisions about which to market, how to package, and how much money to spend on developing, promoting and distributing (Burnett, 1996). Furthermore, who are the consumers of popular music? A study (1990) in the United States conducted by the Recording Industry Association of America (RIAA) shows that in terms of total dollars spent on phonograms of all kinds, 10 to 14 year olds are purchased 9 per cent of all music, 15 to 19 year olds 23 per cent, 20 to 24 year olds 22 per cent, 25 to 34 year olds 24 per cent, and the 35-plus group purchased 22 per cent of recorded music (Burnett, 1996). Based on these data, each age group above 20 years touches more than 20 percent. Fans of boy bands in Japan who are working women with financial abilities can be said to be in the category above 20 years because they already have more income; with data that at the age of 20 years, women in Japan were still in college. 
The typical boy band is made up of four or five young, each with distinct physical qualities, brought together into archetypes, which together make up something approximating a whole: the leader, the joker, the cute baby, and maybe the sexy one (Jarman-Ivens, 2007). Each archetype is designed to bring about some kind of desire on the part of the audience, that is a desire to "mother," a desire to be, a desire to have, and so on (Jarman-Ivens, 2007). Membership structure of a boy band from various countries, including Japan, usually also has such positions or roles. Each group has a leader who is usually formed with charisma or authority and the other members are formed with certain characteristics. Every boy band that has members with certain characteristics (cute, sexy, etc.) usually also has special fans for each of its members - not always like the boy band as a whole group. That way, fans are free to choose which members they like with characteristics.

Women do exist and idols do have agency, but there is an economy to produce and reproduce them as images (Galbraith and Karlin, 2012). If they are formed into a certain figure, in this context idol, then it can be ascertained that producers or agencies form them according to market tastes. Consumers or markets that consume them are also known as gatekeepers. Gatekeepers are the people who make key decisions about whether or not to select certain materials for production and distribution (Burnett, 1996). That is, the fans or gatekeepers turned out to choose to eat boy bands - products sold by the Japanese popular music industry, so that the boy band became a new trend after 2000. As it was in the state before, there were two boy bands occupying the top two positions, namely Exile and Arashi. Both boy bands are displayed with different images. Arashi is formed with a "neat" image and a "smooth" face and charming appearance. In contrast to Arashi, Exile is displayed with an image "nothing" and not with a "charming" image. This is shown in the appearance of Exile members who do not raise the image of "smooth face" and neat. In my opinion, these differences are influenced also by the type of music they carry. Exile's songs are more R \& B nuanced and electronic dance music so it is natural that they are not formed with a physically attractive appearance. Although the two groups have a different look, both of them are able to compete in the popular Japanese music industry after 2000.

The majority of boy bands members have been cute or even a little bit rugged, but their primary cultural function is just to awaken desire in the audience, not to bring sexual desire fully to the surface (Jarman-Ivens, 2007). But in reality, the passion of the fans just woke up. Taking the example of one of the boy band members from SMAP, Kimura Takuya, he was chosen to be "the guy we 'll most like to have sex with" in the popular women' $\mathrm{s}$ fashion magazine. Although in reality, their desire is ultimately limited to fantasy and not real physical activity. That is, this can also apply to fans of other boy bands, including Arashi or Exile. In addition, female fans according to Matsumoto (2007) stated that they have a desire to use their money for idols from Johnny's Entertainment. They also feel satisfaction in "accompanying" their idols to grow and develop as kids whom they feel attracted to (Galbraith and Karlin, 2012). From this presentation, female fans consume idols based on psychological aspects such as sexual arousal or just a feeling of wanting to own, which is supported by the presence of financial ability.

The financial ability of women in Japan has undergone a change. The data in point 2 shows that women's income is slowly increasing. Increased income and the formation of a trend indicate that they have spare money to spend in meeting their leisure and pleasure needs. The availability of spare money means that some women have more money to spend, and they 
choose to consume boy bands. From these activities, women who spend their money to consume popular music industry products get satisfaction. We can say that women who have financial ability and psychological satisfaction are in a fairly "safe" condition. The author does not use "optimal conditions" because like the previous explanation, there has not been a single study that can define well-being absolutely or surely.

Based on the background and explanation above, there are two boy bands who won the Best Artist of the Year position, namely Arashi and Exile. Even though both of them have achieved that position, the two agencies that overshadow the boy band have different strategies. Exile which is under Avex Group does not have its own site. In addition, their songs can be accessed easily through platforms such as iTunes, Spotify, and so on. They also released MV which can be accessed easily via Youtube. Unlike Exile, Arashi under Johnny's Entertainment has a more exclusive impression. Arashi has its own site and different fanite sites and fans can join only when making paid transactions. Arashi songs can also be heard if we buy the album, because it cannot be accessed through platforms like iTunes and Spotify. In addition, their MV cannot be accessed via Youtube. Associated with an explanation of consumerism, then we can see two types of boy band and fan relationships. First, is a type of boy band that is not exclusive so fans can access easily. Second, the exclusive type of boy band so fans have to pay extra for just listening to the song. Both of these types are equally trending in Japanese society. If we examine one more point, we can say that Arashi fans are more certain to have more financial ability. This is due to the exclusive fansite and limited access, so that fans who are able to access these things, certainly have the financial ability.

\section{CONCLUSION}

After seeing the presentation of the above points, it can be concluded that increasing the financial capacity of women after the economic recession in Japan affected the boy band trends offered by the Japanese popular music industry. The formation of the rising boy band trend after 2000 occurred because women with financial power consumed them. Famous boy bands such as Exile and Arashi are two idol groups. The reasons for consuming boy bands formed as commodities are various, some of which are to fulfill their sexual fantasies and channel unconscious maternal instincts, but basically these has the core of leisure and pleasure. The author draws conclusions that are more inclined to the consumption process and not the production-distribution process because according to the author, a product will not become a trend if no one buys. It's the same as boy band. They are formed in such a way as products or commodities by entertainment agencies as producers. With the fans who choose to consume them, then they become a new trend. If the product they offer is no one to buy, then the boy band will not be a big trend - it might sell, but it doesn't hit now. This will also not happen without the financial ability of female fans.

Changes in the condition of women's financial capacity from oppressed conditions to better conditions can be said to be a process towards a condition of well-being. The condition of women who have financial ability and get satisfaction from consuming popular music industry products can also be said to be the process towards a well-being condition. The occurrence of this process in its journey was able to influence several things, one of which led to the formation of a trend in the music industry. Thus, this shows that the financial capacity of women working in Japan is increasing and is able to influence the formation of new trends in 
the Japanese popular music industry. In addition, it does not rule out the possibility that new trends will emerge in the future, depending on the economic conditions of the community in the future.

\section{ACKNOWLEDGEMENT}

This research based on grant scheme of PITTA (Publikasi International Terindeks untuk Tugas Akhir) 2018 or also known as Indexed International Publications for Final Projects toward Universitas Indonesia students.

\section{REFERENCES}

[1]. Aronsson, Anne Stefanie. (2015). Career Women in Contemporary Japan: Pursuing Identities, Fashioning Lives. New York: Routledge.

[2]. Billson, Janet Mancini. Fluehr-Lobban, Carolyn. eds. (2013). Female Well-being: Toward a Global Theory of Social Changes. Zed Books.

[3]. Bourdaghs, Michael. (2012). Sayonara America, Sayonara Nippon: A Geopolitical Prehistory of J-pop. Columbia University Press.

[4]. Burnett, Robert. (1996). The Global Jukebox: The International Music Industry. Taylor and Francis e-library.

[5]. Choi, Jung Bong dan Roald Maliangkay. (2015). K-pop: The International Rise of the Korean Music Indsutry. Routledge.

[6]. Creswell, John W. (2013). Research Design Pendekatan Kualitatif, Kuantitatif, dan Mixed, Edisi Ketiga. Yogyakarta: Pustaka Pelajar.

[7]. Flick, Uwe. (2015). Introducing Research Methodology (2nd ed.). Sage Publications, Ltd.

[8]. Garon, Sheldon. (1997). Molding Japanese Minds: The State in Everyday Life. Princeton University Press.

[9]. Galbraith, Patrick W. (2009). Moe: Exploring Virtual Potential in Post-Millennial Japan.

[10]. Galbraith, Patrick W. Karlin, Jason G. eds. (2012). Idols and Celebrity in Japanese Media Culture. Palgrave Macmillan.

[11]. Haghirian, Parissa. (2011). Japanese Consumer Dynamics. Palgrave Macmillan.

[12]. Jarman-Ivens, Freya. (2007). Oh Boy!: Masculinities and Popular Music. Routledge.

[13]. Mitsui, Toru. (2014). Made in Japan. Routledge.

[14]. Mulvey, Laura. (1989). Visual and Other Pleasures. Macmillan.

[15]. Negus, Keith. (1996). Popular Music in Theory: An Introduction. Wesleyan University Press.

[16]. Sato, Barbara. (2003). The New Japanese Woman: Modernity, Media, and Women in Interwar Japan. United States of America: Duke University Press.

[17]. Stevens, Carolyn S. (2009). Japanese Popular Music: Culture, Authenticity, and Power. Routledge.

[18]. Shirahase, Sawako. (2014). Social Inequality in Japan. New York: Routledge.

[19]. Takeuchi, Yo. (2011). Daigaku no Karyuuka. NTT Shuppan.

[20]. Yu, Wei-Hsin. (2009). Gendered Trajectories: Women, Work, and Social Change in Japan and Taiwan. Stanford University Press. 
[21]. Custers, Peter. (1991). Women's Labour in Japanese Economy. Economic and Political Weekly, Vol. 26 (June, 1991). Pp. 1415-1417, 1419-1422.

[22]. Dasgupta, Romit. 2009. The "Lost Decade" of the 1990s and Shifting Masculinities in Japan. Culture, Society, and Masculinity, Vol. 1, Issue 1, pp. 79-95. http://mensstudies.com ISSN 1941-5591

[23]. Fairchild, Charles. (2015). Crowds, Clouds, and Idols: New Dynamics and Old Agendas in the Music Industry, 1982-2012. American Music, Vol. 33, No. 4 (Winter 2015), pp. 441-476.

[24]. Fukuda, Setsuya. (2013). The Changing Role of Women's Earnings in Marriage Formation in Japan. The Annals of the American Academy of Political and Social Science, Vol. 646 (March, 2013), pp. 107-128.

[25]. Hori, Yoko. (2017). Jogakusei: A Cultural Icon of Meiji Japan. Tesis. University of Kansas: diakses melalui ProQuest.

[26]. Lee, Hyunji. (2018). A 'Real' Fantasy: Hybridity, Korean drama, and Pop cosmopolitans. Media, Culture \& Society (2018) Vol. 40 (3) 365-380.

[27]. Manabe, Noriko. (2008). New Technologies, Industrial Structure, and the Consumption of Music in Japan. Asian Music, Vol. 39, No. 1(Popular Music in Changing Asia) (Winter-Spring, 2008), pp. 81-107.

[28]. McLeod, Ken. 2013. Visual Kei: Hibridity and Gender in Japanese Popular Culture. Young (21) 4 309-325. Sage Publications and Young Editorial Group. http://remotelib.ui.ac.id:5914/doi/pdf/10.1177/1103308813506145

[29]. Nuita, Yoko. (1972). Continuing Education of Women in Japan. Improving College and University Teaching, Vol. 20, No.1 (Winter, 1972), pp. 66-68.

[30]. Yamamoto, Yuki. (2013). Meanings of Graduate Education for Women in Japan: A Study of the University of Tokyo Alumnae in the Social Sciences and Humanities. Disertasi. University of Wisconsin-Madison: diakses melalui ProQuest.

[31]. http://www.riaj.or.jp/

[32]. https://www.oricon.co.jp/rank/

[33]. http://www.japanesestudies.org.uk/articles/2009/Galbraith.html

[34]. http://www.mext.go.jp/

[35]. http://www.mhlw.go.jp/

[36]. http://www.gender.go.jp/

[37]. http://www.garbagenews.net/archives/2014387.html 
